Research Article

\title{
Contamination Level of Chromium, Iron, Nickel, Lead and Cobalt in Soil from an Agricultural area of Urmar Bala, Peshawar Pakistan
}

\author{
Fazal Wahid ${ }^{1}$, Arif Ullah Shah ${ }^{1}$, Muhammad Rahim ${ }^{2 *}$, Fazal Dad ${ }^{1}$, Nadir Khan ${ }^{1}$, Saqib Ullah ${ }^{1}$, Yasir Ali ${ }^{1}$ \\ and Sayed Ashfaq Ali Shah ${ }^{3}$
}

${ }^{1}$ Department of Chemistry, Government College Peshawar, Khyber Pakhtunkhwa, Pakistan; ${ }^{2}$ School of Chemical Sciences, Universiti Sains Malaysia, 11800 Pulau Penang, Malaysia; ${ }^{3}$ Department of Chemistry, Government Post Graduate College No.1, Abbottabad, Pakistan.

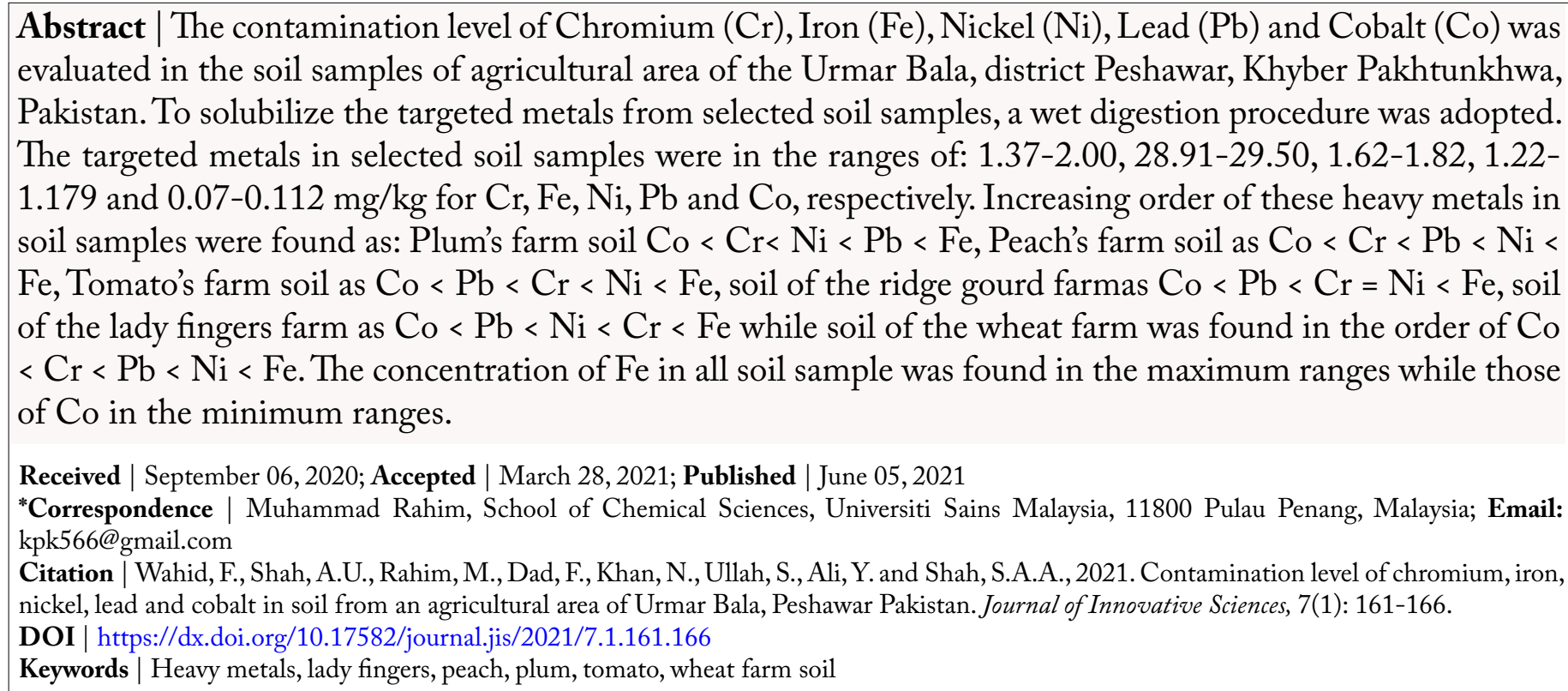

\section{Introduction}

$\mathrm{T}$ he pollution of our adjacent environment with heavy metals is becoming a big monster in many regions of the world especially industrial zones, metropolises and modern agricultural centres due totheir non-biodegrable nature, toxicity, bioaccumulation and subsequent bio-magnifications (Rahim and Mas Haris, 2019; Huihui et al., 2020). Any metallic element having a density greater than $5 \mathrm{~g} / \mathrm{cm}^{3}$ is referred to as a heavy metal. Rapid industrialization, anthropogenic lifestyle and the wide use of man-made chemicals are the major sources of metal toxicity in environment (do Carmo Ramos et al., 2016; Rahim et al., 2016). Elements such as Fe,
$\mathrm{Zn}, \mathrm{Mn}, \mathrm{Cu}, \mathrm{Co}$ and $\mathrm{Ni}$ plays a crucial role in the normal growth and some vital functions of living organisms if present in trace amount as micronutrients, however, becomes a matter of concern if exceed their permissible levels (Rahim et al., 2014; Zhang et al., 2020; Ilieva et al., 2020). Such metals become severely toxic beyond the threshold levels and can lead to various problems due to over-doses. Another list of metals including $\mathrm{Pb}, \mathrm{As}, \mathrm{Cd}, \mathrm{Cr}$ and $\mathrm{Hg}$ also find their way into the surrounding environment through various anthropogenic activities and finally seep into living tissues through food chain (Ahmad et al., 2014; Krishna and Mohan, 2014). Such metals are of great concern for humanity since their long time exposure causes acute toxicities. 
Soil constitutes an essential component of mother nature for life. The minerals and organic materials constituting the soil play a vital role in plant growth and other developmental activities (Ahluwalia and Goyal, 2007; Nwaogu et al., 2014). Heavy metals occur in soil naturally because of geological processes like erosion of underground materials (Chishti et al., 2011). Soil may also have contaminated by heavy metals through effluents from rapidly expanding industrial zones, leaded gasoline and paints, spillage of crude oils, disposal of municipal wastes having high metal contents and modern forming practices such as extensive application of inorganic fertilizers, animal manures and pesticides for greater agricultural outputs (Irmak et al., 2008; Liu et al., 2020). Pollution of agricultural soil with heavy metals have far reaching consequences for the vegetables and crops grown on such soil in two ways, firstly in relation to the very growth and secondly in relation to their consumption as food (Arif et al., 2020; Kim et al., 2020). From the soil through food chain, heavy metals may accumulate in living bodies including humans and their excess in hosts may become ultimately toxic (Rahim et al., 2016; Rahim and Mas Haris, 2019; Khan et al., 2020; Saqib et al., 2020). The exposure of humans and higher animals to various heavy metals for longer duration may ultimately leads to mental lapse, kidney failure, gastrointestinal colic, lung cancer and central nervous system disorder (Rahim et al., 2016). The present study provides a base-line data for the levels of five metals in targeted soil samples in relation to human health.

\section{Materials and Methods}

\subsection{Study area}

The current study was conducted in Urmar Bala of district Peshawar, Khyber Pakhtunkhwa, Pakistan. Geographical coordinates of this area are: $33^{\circ} 57^{\prime} 0^{\prime \prime}$ North, and $71^{\circ} 41^{\prime} 0$ " East. It is a popular agricultural area and many vegetables and fruits are grown here which are consumed locally and marketed other parts of the region. Google map of the study area is shown in Figure 1.

\subsection{Chemicals and instruments}

Hydrochloric Acid (35-38 \% Purity), Nitric Acid (65$68 \%$ Purity), Water (Double Distilled), Polyethylene Containers for sampling, Atomic Absorption Spectrometer (AAS), model AAS 700, Perkin Elmer, USA.

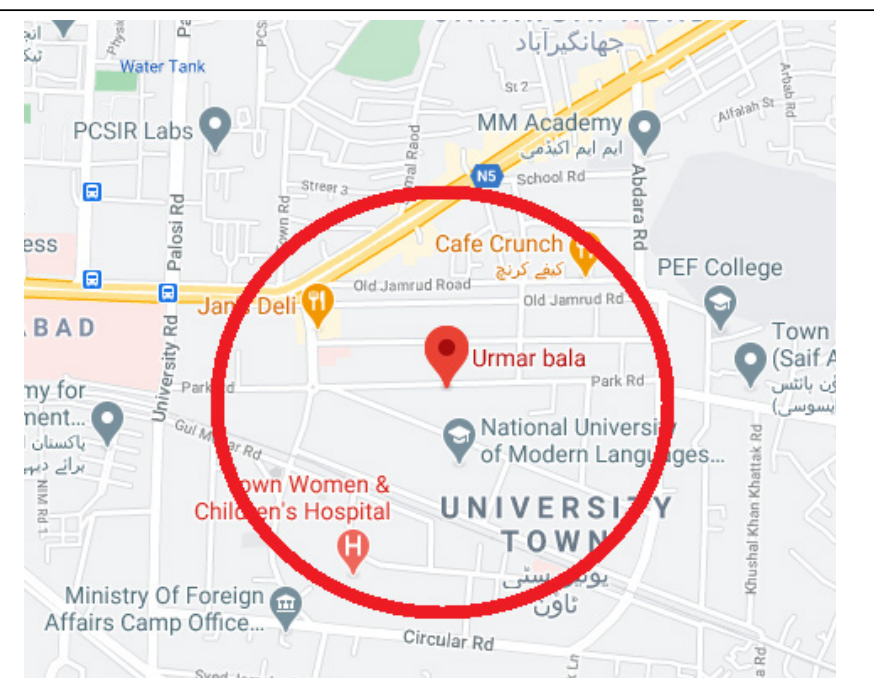

Figure 1: Google map of the study area.

\subsection{Collection of soil samples and pretreatment}

Soil samples for cultivation of selected fruits and vegetables were obtained from various farm houses in Urmar Bala, district Peshawar in summer 2019. Soil samples weighing approximately $1 \mathrm{~kg}$ each were taken with the help of soil auger from the upper layer at a depth of $0-15 \mathrm{~cm}$ for each targeted location. Each soil sample was labelled on the spot and coordinates were inscribed on it. The samples were then shifted to the chemistry lab. of Government College Peshawar for experimental work. Each soil sample was air dried and then grinded with porcelain Mortar and Pestle. The grinded materials were passed through $0.5 \mathrm{~mm}$ sieve and then stored in good quality clear Polythene bags for further analysis. The flowchart diagram is shown in Figure 2.

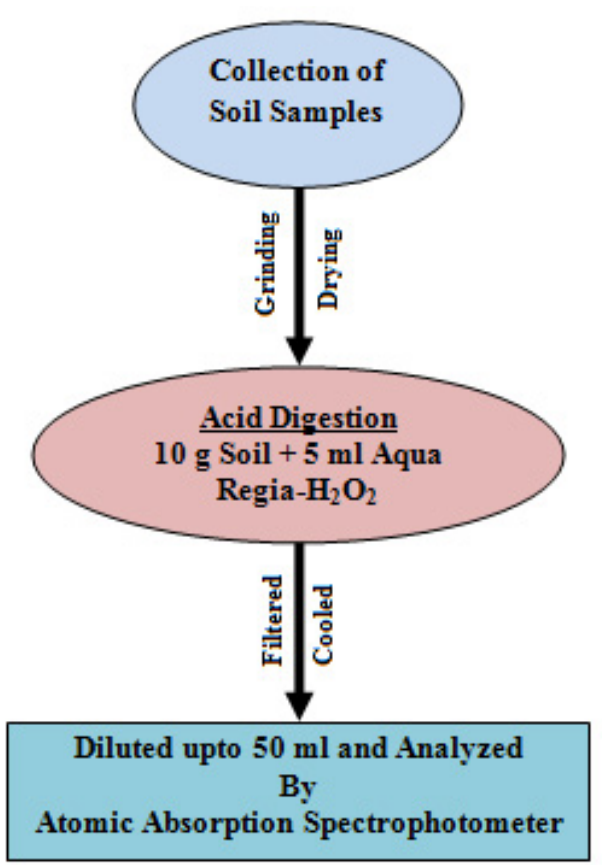

Figure 2: Flowchart of the experimental work. 
Table 1: Average concentration ( $\mathrm{mg} / \mathrm{kg}$ ) of $\mathrm{Cr}, \mathrm{Fe}, \mathrm{Ni}, \mathrm{Pb}$ and $\mathrm{Co}$ in the soil of selected agricultural farms.

\begin{tabular}{llllll}
\hline Sampling site & \multicolumn{5}{c}{ Selected heavy metals } \\
\cline { 2 - 6 } & $\mathrm{Cr}$ & $\mathrm{Fe}$ & $\mathrm{Ni}$ & $\mathrm{Pb}$ & $\mathrm{Co}$ \\
\hline Plum farm soil & $1.47 \pm 0.002$ & $295.01 \pm 3.782$ & $1.69 \pm 0.030$ & $1.79 \pm 0.000$ & $0.49 \pm 0.006$ \\
Peach farm soil & $1.52 \pm 0.014$ & $294.00 \pm 5.720$ & $1.82 \pm 0.033$ & $1.56 \pm 0.025$ & $0.07 \pm 0.001$ \\
Tomato farm soil & $1.42 \pm 007$ & $294.11 \pm 11.092$ & $1.73 \pm 0.000$ & $1.22 \pm 0.000$ & $0.49 \pm 0.000$ \\
Ridge gourd farm soil & $1.62 \pm 0.025$ & $291.73 \pm 0.382$ & $1.62 \pm 0.000$ & $1.17 \pm 0.009$ & $0.60 \pm 0.002$ \\
Lady fingers farm soil & $2.00 \pm 0.040$ & $290.20 \pm 1.094$ & $1.63 \pm 0.007$ & $1.49 \pm 0.045$ & $0.47 \pm 0.000$ \\
Wheat farm soil & $1.37 \pm 0.008$ & $289.09 \pm 0.555$ & $1.64 \pm 0.018$ & $1.57 \pm 0.003$ & $1.12 \pm 0.017$ \\
FAO/WHO (Safe limit) & 100 & 50000 & 50 & 100 & 50 \\
\hline
\end{tabular}

\subsection{Digestion of soil samples}

Wet digestion procedure was adopted for solubilizing the targeted metals from selected soil samples. In this method, $10 \mathrm{~g}$ each of the already processed soil sample was accurately weighed and taken turn by turn into the digestion tube. $5 \mathrm{ml}$ Aqua regia (3:1 of $\mathrm{HCl}$ and $\mathrm{HNO}_{3}$ ) and $1.6 \mathrm{ml} \mathrm{H}_{2} \mathrm{O}_{2}$ were poured into the digestive tube. The digestion tube was kept in furnace for 150 minutes to facilitate the solubility of metals in Aqua regia- $\mathrm{H}_{2} \mathrm{O}_{2}$ solution. The process was repeated for all soil samples. After completion of digestion process, samples were cooled and filtered. The filtrate of all soil samples were then diluted to $50 \mathrm{~mL}$ by adding distilled water and analyzed by Atomic Absorption Spectrophotometer ( $A A S$ 700, Perkin Elmer, USA) installed at Centralized Resource Laboratory (CRL), University of Peshawar, Pakistan.

\section{Result and Discussion}

The average concentrations of the selected heavy metals, $\mathrm{Cr}, \mathrm{Fe}, \mathrm{Ni}, \mathrm{Pb}$ and $\mathrm{Co}$ in targeted soil samples along with the $\mathrm{WHO} / \mathrm{FAO}$ maximum permissible limits are shown in Table 1.

\subsection{Chromium}

Chromium plays an important role in several metabolic activities of humans including those of cholesterol, fat and glucose at optimum levels of presence. Its deficiency in the body is responsible for several disorders such as hyperglycemia, elevation in boy fats levels and a lower sperm count rate. However, at higher concentration levels, it becomes toxic and carcinogenic (Rahim et al., 2014, 2016). Chromium concentration in soil samples was ranged from 1.37 to $2 \mathrm{mg} / \mathrm{kg}$ as shown in Figure 3. Highest concentration in the range of $2 \mathrm{mg} / \mathrm{kg}$ for chromium was found in the soil of Lady Fingers farm, while lowestlevel of $1.37 \mathrm{mg} / \mathrm{kg}$ observed for wheat farm soil. Level of chromium in all soil samples is in the order: wheat farm soil < tomato farm soil < plum farm soil < peach farm soil < ridge gourd farm soil < lady fingers farm soil.

\subsection{Iron}

Iron is an essential element needed by all plants and animals for their diverse metabolic activities. It takes part in DNA synthesis as well as free electrons and oxygen transport to various body parts. However, the presence of iron in human body at higher levels is associated with several disorders including tissues damage and anemia (Rahim et al., 2016). Iron concentration in the current study was found in the range of 289.1 to $295.0 \mathrm{mg} / \mathrm{kg}$ and projected graphically in Figure 4. Its highest concentration of $295.0 \mathrm{mg} / \mathrm{kg}$ was observed for plum farm soil while lowest $(289.1 \mathrm{mg} / \mathrm{kg})$ in wheat farm soil. The increasing order of iron in soil samples is: wheat farm soil < lady fingers farm soil < ridge gourd farm soil < peach farm soil < tomato farm soil < plum farm soil.

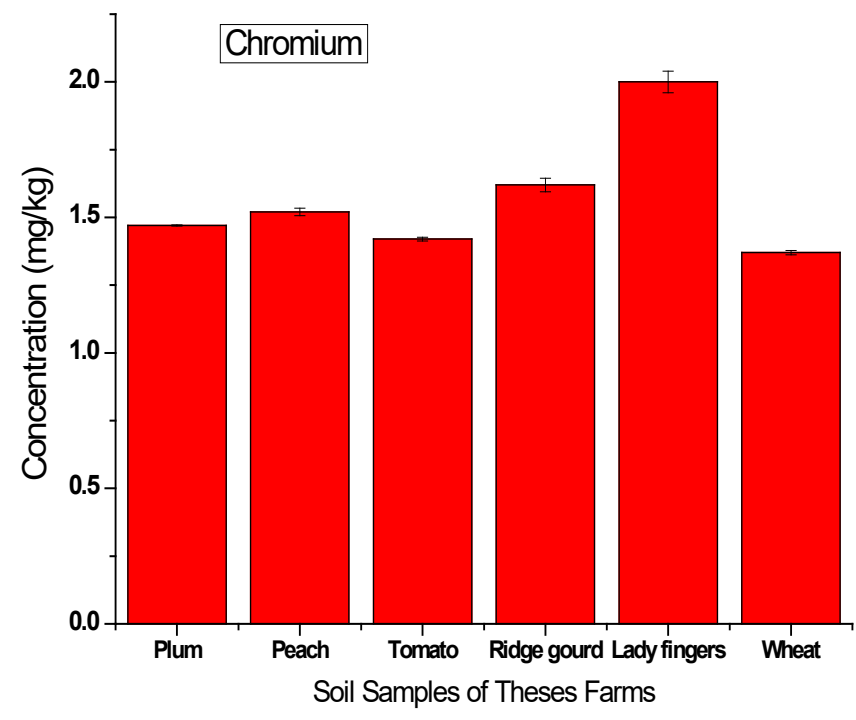

Figure 3: Concentration $(\mathrm{mg} / \mathrm{kg})$ of chromium in the soil of selected farms. 


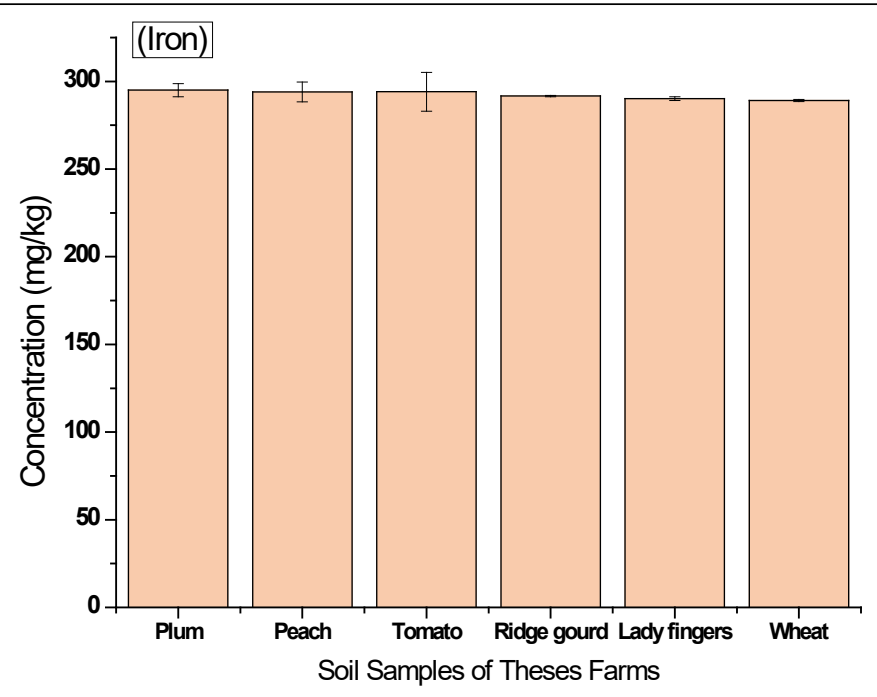

Figure 4: Concentration $(\mathrm{mg} / \mathrm{kg})$ of iron in the soil of selected farms.

\subsection{Nickel}

Nickel is an important metal required by human body for lipid regulation inside tissues and production of haematids. However its presence in the body beyond permissible levels can lead to several ailments such asloss in body weight, loss of eye sight, failure of heart liver dysfunction and irritation of skin (Poonkothai and Vijayavathi, 2012). Nickel concentrations in current study were observed in the range of 1.62 to $1.82 \mathrm{mg} / \mathrm{kg}$. Comparison of various soil sample reveals that the level of nickel $(1.83 \mathrm{mg} / \mathrm{kg})$ is highest for peach farm soil while lowest $(1.62 \mathrm{mg} / \mathrm{kg})$ for ridge gourd farm soil as graphically displayed in Figure 5. The increasing order of nickel in soil samples is: ridge gourd farm soil < lady fingers farm soil < wheat farm soil < plum farm soil < tomato farm soil < peach farm soil.

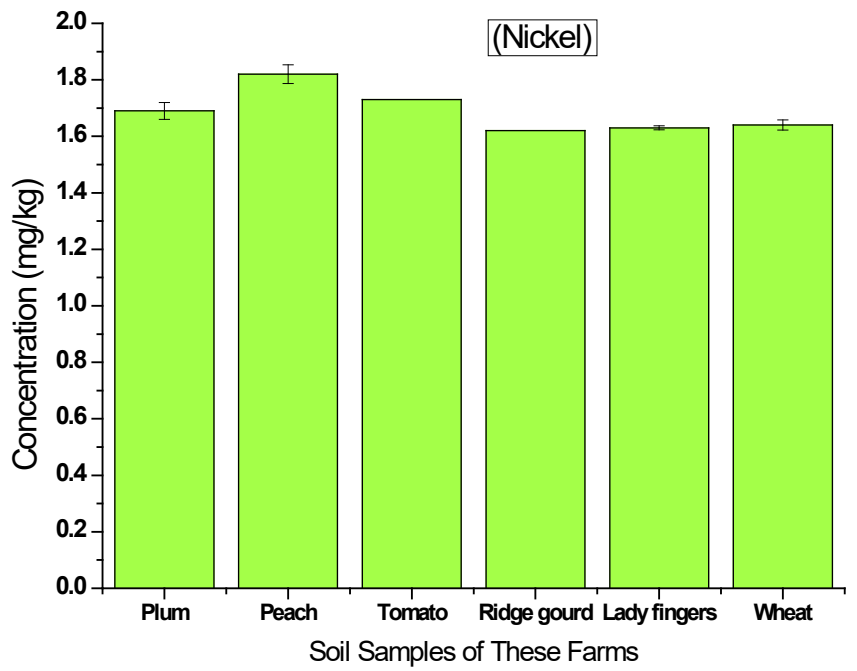

Figure 5: Concentration $(\mathrm{mg} / \mathrm{kg})$ of nickel in the soil of selected farms.
3.4 Lead

Lead is non-essential heavy metal and its accumulation in body at an elevated level and can causes headache, anaemia, damage of brain and central nervous system (Nas and Ali, 2018). Lead contents in present investigation were found in the range of 1.17 to $1.79 \mathrm{mg} / \mathrm{kg}$. The concentrations of lead in various soil samples are: ridge gourd farm soil is $1.17 \mathrm{mg} /$ $\mathrm{kg}$, tomato farm soil, $1.22 \mathrm{mg} / \mathrm{kg}$; lady fingers farm soil, $1.49 \mathrm{mg} / \mathrm{kg}$; peach farm soil, $1.56 \mathrm{mg} / \mathrm{kg}$; wheat farm soil, $1.57 \mathrm{mg} / \mathrm{kg}$ while that in plum farm soil is $01.79 \mathrm{mg} / \mathrm{kg}$. The highest concentration of lead was reported for plum farm soil while lowest for tomato farm soil. The average concentrations are shown in Figure 6.

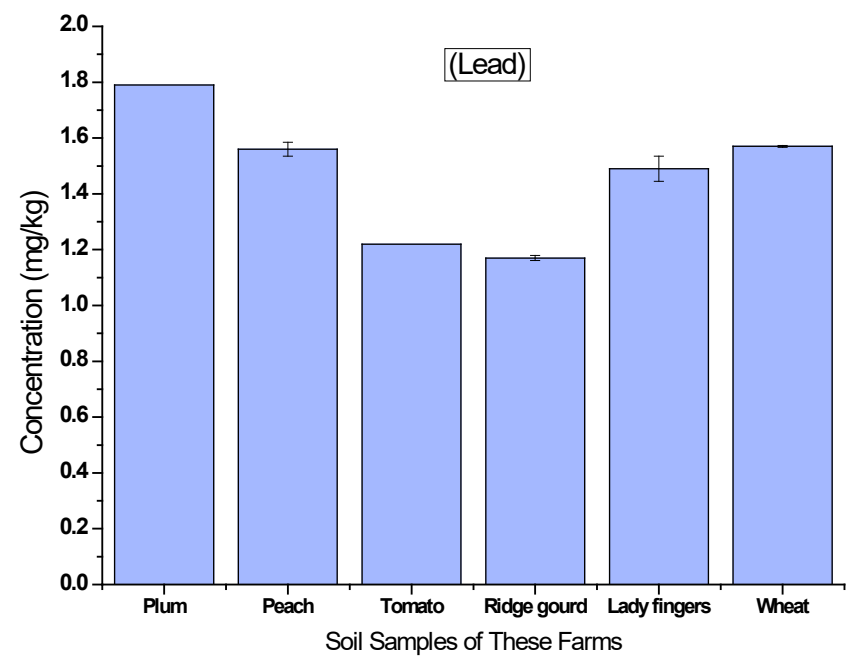

Figure 6: Concentration $(\mathrm{mg} / \mathrm{kg})$ of lead in the soil of selected farms.

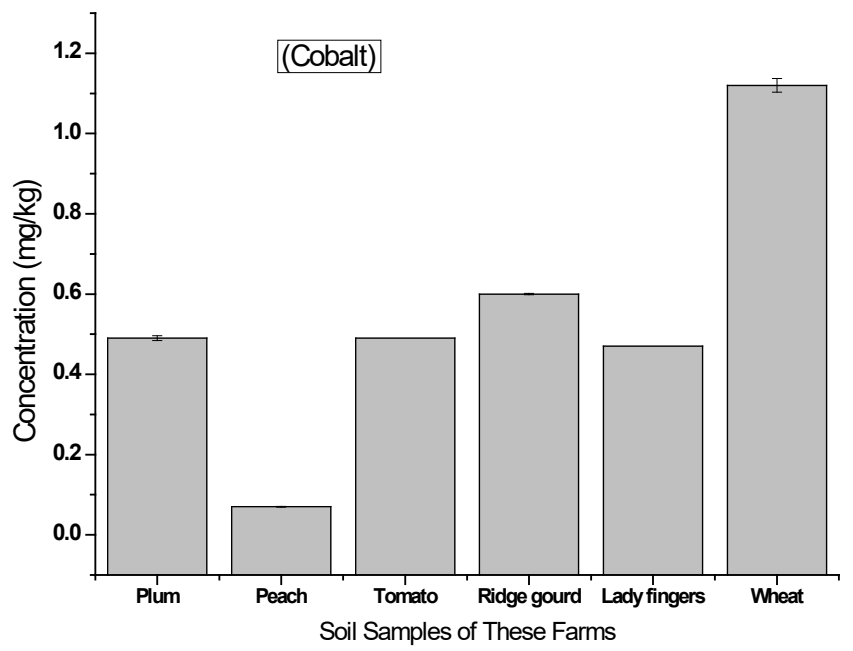

Figure 7: Concentration $(\mathrm{mg} / \mathrm{kg})$ of cobalt in the soil of selected farms.

3.5 Cobalt

Cobalt is useful to human for its utility in production 
of Cobalamine (vitamin $\mathrm{B}_{12 \text { ), }}$ however at high levels, cobalt is responsible for dermatitis, lungs and heart diseases (Gavrilenko et al., 2015). In the present study, cobalt concentrations in various soil samples were observed in the range of 0.07 to $0.112 \mathrm{mg} / \mathrm{kg}$ and these are shown graphically in Figure 7. The level of cobalt in various soil samples are: Peach farm soil, $0.07 \mathrm{mg} / \mathrm{kg}$; lady fingersfarm soil, $0.47 \mathrm{mg} / \mathrm{kg}$; plum farm soil, $0.49 \mathrm{mg} / \mathrm{kg}$; tomato farm soil, $0.49 \mathrm{mg} / \mathrm{k}$; ridge gourd farm soil, $0.60 \mathrm{mg} / \mathrm{kg}$; wheat farm soil, $0.112 \mathrm{mg} / \mathrm{kg}$.

\section{Conclusions and Recommendations}

Various research findings reveal that the presence of heavy metals at an elevated level in irrigation water and soil is responsible for penetration and concentration of these in vegetables, fruits and cereal crops. Such food staples when consumed on regular basiscauses adverse effect on human health. The health concerns necessitated the assessment of $\mathrm{Cr}$, $\mathrm{Fe}, \mathrm{Ni}, \mathrm{Pb}$ and $\mathrm{Co}$ in soil samples collected from the agricultural farms of the selected fruits and vegetables in the area of Urmar, Peshawar, Northwest Pakistan. Soil samples were collected from the selected fruits and vegetables farms in summer 2019. Acid digestion method was used in order to extract metal ions from the soil samples. The concentration was ranged from 1.37 to $2.00,28.91$ to $29.50,1.62$ to 1.82 and 1.22 to 1.179 and 0.07 to $0.112 \mathrm{mg} / \mathrm{kg}$ for $\mathrm{Cr}, \mathrm{Fe}, \mathrm{Ni}, \mathrm{Pb}$ and $\mathrm{Co}$, respectively. The study revealed that the average concentration of $\mathrm{Fe}$ was highest and that of cobalt lowest among all soil samples. Moreover, the results that observed concentrations of all five metals were well below their maximum safe limit set by FAO/ WHO. It might be due to limited industries and less use of pesticides. Although, the observed values are below the WHO standards, but presence of heavy metals in water, fruits and other food commodities should be monitored in the studied area.

\section{Acknowledgements}

The authors acknowledge the facilitating support of Centralized Resource Laboratory (CRL), Department of Physics, University of Peshawar, Pakistan.

\section{Novelty Statement}

This investigation highlights the occurrence of $\mathrm{Cr}, \mathrm{Fe}$, $\mathrm{Ni}, \mathrm{Pb}$ and $\mathrm{Co}$ at the lower levels than the WHO/ Journal of Innovative Sciences

June 2021 | Volume 7 | Issue 1 | Page 165
FAO guidelines in agricultural soil samples. The lower levels of $\mathrm{Cr}, \mathrm{Fe}, \mathrm{Ni}, \mathrm{Pb}$ and $\mathrm{Co}$ indicated that the soil is safe for agricultural activities.

\section{Author's Contribution}

WF, AAU conceptualized the study. DF, KN recorded the data. RM and US statistical analyzed the data. AY and SSAA wrote Introduction section of the manuscript. WF and SAU wrote methodology and results. RM edited the format of the graphs and tables. RM and SSAA reviewed the manuscript. The final draft was approved for submission by all the authors.

\section{Conflict of interest}

The authors have declared no conflict of interest.

\section{References}

Ahluwalia, S.S., and Goyal, D., 2007. Microbial and plant derived biomass for removal of heavy metals from wastewater. Bioresource Technology, 98(12): 2243-2257. https://doi.org/10.1016/j. biortech.2005.12.006

Ahmad, N., Rahim, M., and Haris, M.R.H.M., 2014. Toxicological impact assessment of heavy metals in human blood and milk samples collected in District Shangla, Pakistan. Science International, 26(1): 223-226.

Arif, U.S., Alrawi, I.L., Wahid, F., Ali, R., Rahim, M., and Sultana, Q. 2020. Assessment of some heavy metals in selected vegetables, fruits and their respective soil. Journal of Applied and Emerging Sciences. 10(1): 70-74. https://doi. org/10.36785/BUITEMS.JAES.376

Chishti, K.A., Khan, F.A., Shah, S.M.H., AsifKhan, M., Khan, J., Shah, S.M.M., and Hussain, I., 2011. Estimation of heavy metals in the seeds of blue and white capitulum's of sil ybum marianum grown in various districts of pakistan. Journal of Basic and Applied Sciences, 7(1): 45-49.

do Carmo Ramos, S.N., Xavier, A.L.P., Teodoro, F.S., Gil, L.F., and Gurgel, L.V.A., 2016. Removal of cobalt (II), copper (II), and nickel (II) ions from aqueous solutions using phthalate-functionalized sugarcane bagasse: Mono and multicomponent adsorption in batch mode. Industrial Crops and Products, 79: 116130. https://doi.org/10.1016/j.indcrop.2015.10.035 Gavrilenko, N.A., Saranchina, N.V., and 
Gavrilenko, M.A., 2015. A colorimetric sensor based on a polymethacrylate matrix with immobilized 1-(2-pyridylazo)-2-naphthol for the determination of cobalt. Journal of Analytical Chemistry, 70(12): 1475-1479. https://doi. org/10.1134/S1061934815120060

Huihui, Z., Li X., Xu, Z., Wang, Y., Teng, Z., Meijun, A., Zhang, Y., Zhu, W., Xu, N., and Sun, G., 2020. Toxic effects of heavy metals $\mathrm{Pb}$ and $\mathrm{Cd}$ on mulberry (Morus alba L.) seedling leaves: Photosynthetic function and reactive oxygen species (ROS) metabolism responses. Ecotoxicology and environmental safety, 195(2020): 110469. https://doi. org/10.1016/j.ecoenv.2020.110469

Ilieva, I., Sainova, I., and Yosifcheva, K., 2020. Toxic Effects of Heavy Metals (Lead and Cadmium) on Sperm Quality and Male Fertility. Acta morphologica et anthropologica, 27: 3-4.

Irmak, S., Surucu, A., and Aydin, S., 2008. The effects of iron content of soils on the iron content of plants in the Cukurova region of Turkey. International Journal of Soil Science, 3: 109-118. https://doi.org/10.3923/ijss.2008.109.118

Khan, N., Wahid, F., Sultana, Q. Saqib, N.U., and Rahim, M., 2020. Surface oxidized and un-oxidized activated carbon derived from Ziziphus jujube Stem, and its application in removal of $\mathrm{Cd}$ (II) and $\mathrm{Pb}$ (II) from aqueous media. SN Applied Sciences, 2(4): 1-11. https:// doi.org/10.1007/s42452-020-2578-6

Kim, D.H., Sang-Wook, P., Deok-Won K., Ji-Su P., Eun-JiO.,JinY.,and KeunY.C.,2020.Evaluation for Interactive Toxic Effects of Binary Heavy Metals on Bacterial Growth and Phosphorus Removal under Co-Culture Condition of Alcaligenes sp. and Pseudomonas sp. Applied Chemistry for Engineering, 31(6): 612-623.

Krishna, A.K., and Mohan, K.R., 2014. Risk assessment of heavy metals and their source distribution in waters of a contaminated industrial site. Environmental Science and Pollution Research, 21(5): 3653-3669. https://doi. org/10.1007/s11356-013-2359-5

Liu, Q., Yanqing S., Ming J., Guoqiang Z., and Changyu L., 2020. Attempt of basin-scale sediment quality standard establishment for heavy metals in coastal rivers. Chemosphere, 245(2020): 125596. https://doi. org/10.1016/j.chemosphere.2019.125596

Nas, F., and Ali, M., 2018. The effect of lead on plants in terms of growing and biochemical parameters: A review. MOJ Eco Environment Science, 3(4): 265-268. https://doi.org/10.15406/ mojes.2018.03.00098

Nwaogu, L.A., Ujowundu, C.O., Iheme, C.I., Ezejiofor, T.N., and Belonwu, D.C., 2014. Effect of sublethal concentration of heavy metal contamination on soil physicochemical properties, catalase and dehydrogenase activities. International Journal of Biochemistry Research and Review, 4(2): 141-147. https://doi. org/10.9734/IJBCRR/2014/6341

Poonkothai, M., and Vijayavathi, B.S., 2012. Nickel as an essential element and a toxicant. International Journal of Environmental Sciences, 1(4): 285-288.

Rahim, M., and Mas Haris, M.R.H., 2019. Chromium (VI) removal from neutral aqueous media using banana trunk fibers (BTF)reinforced chitosan-based film, in comparison with BTF, chitosan, chitin and activated carbon. SN Applied Sciences, 1(10): 1180. https://doi. org/10.1007/s42452-019-1206-9

Rahim,M.,Imdad,U.,Adnan,K.,Haris,M.R.H.M., and Nisar, A., 2014. Spatial distribution and risk assessment of heavy metals from drinking water in District Shangla. Science International(Lahore), 26(4): 1625-1630.

Rahim, M., Mohammad, I., Hassan, W., and Ahmad,N.,2016. Heavy Metal Profile of Shilajit Samples Obtained from Gilgit and Chellas, Pakistan. Journal of Physical Science, 27(2): 139. https://doi.org/10.21315/jps2016.27.2.10

Rahim, M., Ullaha, I., Khan, A., and Mas Haris, M.R.H., 2016. Health risk from heavy metals via consumption of food crops in the vicinity of District Shangla. Journal of the Chemical Society of Pakistan, 38(1): 177-185.

Saqib, N.U., Khan, A., Alam, I., and Rahim, M., 2020. Glass beads immobilized doped $\mathrm{TiO} 2$ NPs with enhanced adsorption efficiency for arsenic (III) from aqueous solution. SN Applied Sciences, 2(4): 1-11. https://doi.org/10.1007/ s42452-020-2207-4

Zhang, P., Xuemei, P., Qinyuan, W., Gang, G., and Yun, H., 2020. Toxic effects of heavy metals on the freshwater benthic organisms in sediments and research on quality guidelines in Poyang Lake, China. Journal of Soils and Sediments, 20(10): 3779-3792. https://doi. org/10.1007/s11368-020-02700-5 